\title{
Thermography-a reflector in health and disease
}

\section{Mini review}

Heat (Warmth) has a profound cognitive impact on humans. ${ }^{1} \mathrm{~A}$ strong relationship exists between life and body temperature, wherein moderate body temperature is co existent with normal health and a high body temperature is seen to have a significant relationship with disease process. ${ }^{1}$

Ancient greeks considered body temperature for the diagnosis of disease. Hippocrates in 400BC showed that the palm of the hand can also be used to assess the skin temperature of sick patients. Wunderlich in 1872, made fever measurements a mandatory practice. Later core body temperature was assessed by reliable thermometers for diagnosing fever. Subsequently it became a routine practice to assess body temperature of all patients. ${ }^{2}$

The temperature of the skin is dynamic and depends on a number of functions, not least of which is the ambient environment. All objects including the human body emit radiation in the infrared spectrum. Wein's law states that the rate at which the maximum energy is emitted is dependent on the temperature of the body. Therefore, temperature is reflected by gauging the infrared radiation radiated by the skin surface. ${ }^{3}$ Thermography, the science of heat recording can be used to record the heat given off by the human body. ${ }^{4}$

The 3 systems of thermography are

a. Liquid crystal thermography

b. Infrared thermography

c. Microwave thermography

Variations in both qualitative as well as quantitative infrared heat radiation has been affirmed in a diversity of disease conditions. ${ }^{3}$

\section{a. Liquid crystal thermography}

The device comprises of pliable rubber sheets with cholesteric crystals inserted within them. Numerous sheets of crystals are attached on a structure with a clear side, which are inflatable within the frame for better adaptability body's shape. Once adapted, the crystals changes color like dark brown color for cool areas and red colors for warmer areas from their neutral color, indicating the temperature distribution over the skin. Subsequently color display is then snapped by Polaroid photography representing the thermogram, used for diagnostic evaluation. ${ }^{1,4,5}$

\section{b. Infrared thermography}

All objects including the human body emit radiation in the infrared spectrum. Wein's law states that the rate at which the maximum energy is emitted is dependent on the temperature of the body. Therefore, temperature of the body can be assessed by gauging the infrared radiation. ${ }^{6}$

Infrared radiation given off by the individual passes through lens and further into a series of briskly rotating mirrors, which chronologically mirror the infrared radiation to the infrared sensor, which is further translated into electrical signals. Further these electric signals are amplified and boosted up a few volts which are then assigned digital values and fed to a computer. The combined data of the input and timing figures from rotating mirrors recreates a digitized
Volume 5 Issue 6 - 2018

\author{
Yadav Karthik D,' Saleem Mohammed, ${ }^{2}$ \\ Saleem Rayeesa, ${ }^{3}$ Sindhe J Raghunand' \\ 'Department of oral medicine and radiology, India \\ ${ }^{2}$ Department of Prosthodontics, India \\ ${ }^{3}$ Department of Conservative and Endodontics, India
}

\begin{abstract}
Correspondence: Karthik D Yadav, Master of Dental surgery, Department of Oral Medicine and Radiology, IOth Milestone, Bommanahalli, Hosur Road, Bangalore-560 102, India, Tel +919902824646, Email karthikyadevd@gmail.com
\end{abstract}

Received: August 01, 2018 | Published: November 26, 2018

thermal image using suitable image analysis software and kept on a computer disk for reference. ${ }^{6-8}$

\section{c. Microwave thermography}

The thermal radiation emitted from the body tissues is captured by the device which has an antenna capable of detecting microwaves of a cylinder of tissue with a dia of $1.5 \mathrm{~cm}$ and depth of $2 \mathrm{~cm}$ in the $3-3.5 \mathrm{GHz}$ range. Microwaves have a depth penetration of $4 \mathrm{~cm}$ and a wavelength of $-10 \mathrm{~cm}$. Here, the microwaves travel unaffected to the skin surface suggestive of true core temperature. ${ }^{9}$

Thermal imaging and temperature measurement have played a major role to evaluate health and disease, with the help of thermometers, thermistors, thermocouples, and liquid crystal imaging systems. Thus further studies are needed to critically evaluate the use of thermography as a promising diagnostic aid in various specialties of dentistry.

\section{Acknowledgments}

None.

\section{Conflicts of interest}

The author declares that there is no conflicts of interest.

\section{References}

1. Anbar M, Gratt B, Hong D. Thermology and facial telethermography. Part I: history and technical review. Dentomaxillofac Radiol. 1998;27(2):6167.

2. Gratt BM, Pullinger A, Sickles E A, et al. Electronic thermography of normal facial structures: a pilot study. Oral Surgery, Oral Medicine, Oral Pathology. 1989;68(3):346-351.

3. Biagioni PA, Longmore RB, McGimpsey JG, et al. Infrared thermography. Its role in dental research with particular reference to craniomandibular disorders. Dentomaxillofac Radiol. 1996;25(3):119-124.

4. Pogrel MA, Erbez G, Taylor RC, et al. Liquid crystal thermography as a diagnostic aid and objective monitor for TMJ dysfunction and myogenic facial pain. J Craniomandib Disord. 1989;3(2):65-70.

5. Ariyaratnam S, Rood JP. Measurement of facial skin temperature. J Dent. 1990;18(5):250-253.

6. White A, Lokhart B, Connolly F, et al. The use of infrared thermography in the evaluation of oral lesions. J Am Dent Assoc. 1986;113(5):783-786. 
7. Gratt B, Anbar M. Thermology and facial telethermography: Part II Current and future clinical applications in dentistry. Dentomaxillofac Radiol. 1998;27(2):68-74.

8. Brelsford KL, Uematsu S. Thermographic presentation of cutaneous sensory and vasomotor activity in the injured peripheral nerve. $J$ Neurosurg. 1985;62(5):711-715.
9. Gazvani MR, Wood SJ, Thomson AJM, et al. Assessment of testicular core temperatures using microwave thermography. Hum Reproduct. 2000;15(8):1723-1726. 